\title{
Isolation and Characterisation of Bioactive Peptides Components from Caprine Milk Casein Fractions
}

\author{
H. Devaraja Naik ${ }^{1 *}$, M. Venkatesh ${ }^{2}$ and H. Arun Kumar ${ }^{2}$ \\ ${ }^{1}$ Department of Livestock products Technology, Veterinary College, Karnataka \\ Veterinary, Animal and Fisheries Science University (Bidar), Hassan, India \\ ${ }^{2}$ Department of Dairy Technology, Dairy Science College, Karnataka Veterinary, Animal and \\ Fisheries Science University (Bidar), Hebbal Bengaluru, India \\ *Corresponding author
}

\section{A B S T R A C T}

\section{Key words \\ Caprine milk, \\ Fractionation, \\ Characterisation, \\ Casein hydrolysates, \\ Bioactive peptides, \\ SDS-PAGE, RP- \\ HPLC \\ Article Info \\ Accepted: \\ 15 October 2018 \\ Available Online: \\ 10 November 2018}

The caprine milk proteins are considered as power house of bioactive peptides, these bioactive peptides may be released in enzymatic hydrolysis(Trypsin $10 \mathrm{mg}$ of enzyme/5 $\mathrm{g}$ of protein) at $\mathrm{pH} 8.0$ and temperature $40^{\circ} \mathrm{C}$ was of casein fractions was carried out at an enzyme- substrate (E: S) ratio of 1:25. Enzymatic hydrolysis of casein fractions was carried out at an enzyme- substrate $(E: S)$ ratio of 1:25. The milk protein from goat milk was extracted by using acid precipitation method and purified using urea fractionation. Fractionation of whole casein from $6.6 \mathrm{M}$ urea to $4.63 \mathrm{M}$ urea yields a precipitate of $\alpha_{\mathrm{s}}$ casein and $\beta$ - casein is obtained by further dilution of the supernatant to $1.7 \mathrm{M}$ urea at $\mathrm{pH}$ of 4.7. Enzymatic hydrolysis of casein fractions was carried out at an enzyme- substrate (E: S) ratio of 1:25 The SDS-PAGE was most widely used method for analyzing protein mixtures qualitatively and RP-HPLC was useful for monitoring protein purification of Bioactive peptides (BAPs). Hydrolysed bioactive peptides of caprine milk proteins are exhibit various physiological effects in the body, such as gastrointestinal, cardiovascular, endocrine, immune, and nervous systems.

\section{Introduction}

Caprine milk has a rich source of proteins and those similar to the major cow milk proteins in their general classifications of $\alpha_{\mathrm{s}}$-caseins, $\beta$ caseins, $\beta$-lactoglobulin, $\alpha$-lactalbumin. It has been reported that $\beta$-casein is the major component $(06-64 \%)$ of goat milk casein, whereas, $\alpha_{\mathrm{s} 1}$ is the major component of cow milk casein (50 - 53.6\%). Level of $\alpha_{\mathrm{s} 2}$ casein $(10-25 \%)$ is relatively higher in goat milk but total of $\alpha_{\mathrm{s} 1}$ and $\alpha_{\mathrm{s} 2}$ casein fractions together are lower than $\alpha_{s^{-}}$fraction alone of cow milk. Such differences might contribute to soft curd forming properties, better digestibility and least allergic to children (Tziboula-Clarke, 2003). The distinctive composition of caprine milk proteins is combined with its nutritional value linked to the liberation of protein fragments during digestion or technological processing, which are able to perform various biological 
activities and wider application to food, drug and various other industries (Sharma et al., 2017). The caprine milk proteins are considered as power house of bioactive peptides, these bioactive peptides may be released in vivo during gastrointestinal digestion by the action of digestive enzymes like pepsin, trypsin or chymotrypsin. Gastrointestinal digestion permits the consequent action of the enzymes present in the small intestine such as pepsin, trypsin or chymotrypsin, which are responsible for protein hydrolysis (Korhonen and Pihlanto, 2003).

\section{Materials and Methods}

\section{Milk samples}

The indigenous and exotic caprine breed milk samples were collected from Sinchana goat and sheep farm, Marenahalli village (Bengalru Rural Dist) and Yashodhavana Goat Farm (Mysuru) and cow milk samples were collected from Dairy Farm, Hebbal, KVAFSU Bengaluru.

\section{Trypsin enzymes}

2000 IU a commercially available enzyme used for the hydrolysis of casein to obtain higher degree of hydrolysis (Enzyme substrate ratio of $1: 25$ ).

\section{Fractionation of casein}

The fractionation of casein from acid whole casein (wet) was followed as per procedure of Hipp et al., (1952) on the basis of differential solubility in urea solution. Fractionation of whole casein from $6.6 \mathrm{M}$ urea to $4.63 \mathrm{M}$ urea yields a precipitate of $\alpha_{\mathrm{s}^{-}}$ casein and $\beta$ - casein is obtained by further dilution of the supernatant to $1.7 \mathrm{M}$ urea at $\mathrm{pH}$ of 4.7 .

\section{Preparation of casein fraction hydrolysates}

The casein fractions $\left(\alpha_{\mathrm{s}^{-}}, \beta-\mathrm{CN}\right)$ fractions of caprine milk was dispersed separately in distilled water at $40^{\circ} \mathrm{C}$ to give a 5 per cent $(\mathrm{w} / \mathrm{v})$ protein concentration and the $\mathrm{pH}$ of the solutions was adjusted to optimum as that of the enzymes using $0.1 \mathrm{~N} \mathrm{NaOH}$. The enzyme trypsin (10 $\mathrm{mg}$ of enzyme $/ 5 \mathrm{~g}$ of protein) at $\mathrm{pH} 8.0$ and temperature $40^{\circ} \mathrm{C}$ was maintained. Enzymatic hydrolysis of casein fractions was carried out at an enzyme- substrate $(\mathrm{E}: \mathrm{S})$ ratio of 1:25 (Nagamani, 2013).

\section{Degree of hydrolysis}

Degree of hydrolysis (DH) was determined by the $\mathrm{pH}$ stat method (Mcdonagh and Fitzgerald, 1998) with slight modification in temperature and strength of alkali used to keep the $\mathrm{pH}$ constant during hydrolysis.

Degree of Hydrolysis $(\mathrm{DH})=\mathrm{B} \times \mathrm{Nb} \times 1 / \alpha \mathrm{s} \times$ $1 / \mathrm{Mp} \times 1 /$ htot $\times 100$

Where,

$\mathrm{B}=$ Base consumption in $\mathrm{ml}$

$\mathrm{Nb}=$ Normality of Base (alkali)

$\mathrm{Mp}=$ Mass of protein in gram $(\mathrm{N} \times \mathrm{fN})$

htot $=$ Total number of peptide bonds in protein substrate (meq/g of protein for casein; htot $=8.2)$

$\alpha=$ Average degree of dissociation of $\alpha-\mathrm{NH}_{2}$ groups $1 / \alpha$ factor was considered.

$\alpha S=\frac{10^{\mathrm{pH}-\mathrm{pKa}}}{1+10^{\mathrm{pH}-\mathrm{pKa}}}$

For casein $\mathrm{pKa}=7.45$ at $\mathrm{pH} 7.5,1 / \alpha=1.89$.

\section{Isolation of Bio-active peptides (BAPs)}

The BAPs were isolated from $\alpha$ and $\beta$ - casein fractions by adapting the method of Fitz Gerald (1998), which is based on the principle that BAPs are soluble at $\mathrm{pH} 4.6$ and 
aggregated with divalent cat-ion such as calcium at neutral $\mathrm{pH}$ of 7.0. BAPs obtained by ethanol extraction were dried overnight in an oven maintained at a temperature of $70 \pm 1^{0}$ $\mathrm{C}$ and stored at $4^{0} \mathrm{C}$ before use.

\section{The chemical composition of BAPs}

The total ash and moisture content of BAPs obtained from hydrolyzed casein protein fractions were evaluated separately as per the procedure of AOAC (1984) whereas, protein content by micro-kjeldhal method as per the procedure of AOAC (1980).

\section{Quantification of BAPs from casein fractions}

The quantification of BAPs from casein fraction was carried out by adapting the method suggested by Bradford (1976).

\section{Molecular weight profile of BAPs}

Sodium Dodecyl Sulphate Polyacrylamide Gel Electrophoresis (SDS-PAGE) was carried out to assess the molecular weight profile of BAPs isolated from enzymatically hydrolyzed casein fractions using trypsin by the method of Laemmli (1976).

Reverse phase High Performance Liquid Chromatography (RP-HPLC)

RP-HPLC was performed for separation and purification of BAPs. The RP-HPLC profile of the BAPs was determined using Shimadzu HPLC system by adapting the procedure followed by Mc Donagh and Fitz Gerald (1998).

\section{Statistical analysis}

Experimental data obtained in the study was analyzed by Randomized column block design as per the method described by Snedecor and
Cochran (1983) to test for ' $F$ ' values to know the statistical significance. Critical Difference (CD) value was calculated to determine whether the treatment means were similar or not. The analysis was done using SPSS software package and MS Excel 2007.

\section{Results and Discussion}

Yield of Bio-active peptides (BAPs) from hydrolyzed casein fractions

It was observed that, after maximum hydrolysis (i.e., $15 \% \mathrm{DH}$ ) the average permeate yield in case of $\alpha_{\mathrm{s}}$-casein and $\beta$ casein were 63 and 85 per cent and 75 and 92 per cent at $1 \mathrm{kDa}$ and $10 \mathrm{kDa}$ respectively. Comparatively, higher yield was obtained from $\beta$-casein hydrolysis than $\alpha_{\mathrm{s}}$-casein hydrolysis after $3 \mathrm{hrs}$. The results are well supported by Shashi kumar (2012); Nagamani, (2013) and Naik et al., (2013) the average permeate yield of casein hydrolysate $\alpha_{\mathrm{s}}$ - casein was 14.8 and $\beta$ - casein was 11.8 per cent respectively (Table 1).

Measurement of absorbance for quantification of Bio-active peptides from caprine milk casein

The absorbency values for these concentrations were 0.122 and 0.157 respectively for $\alpha_{S^{-}}$casein and $\beta$ - casein fractions (Table 2). However, the quantification of $\alpha_{S^{-}}$casein and $\beta$ - casein were 26.8 and $41.2 \mu \mathrm{g}$ per $\mathrm{ml}$ respectively.

The absorbance showed linear relationship with concentration of Bovine serum Albumin. The enzyme hydrolyzed $\beta$-casein showed higher absorbency values compared to $\alpha_{\mathrm{s}^{-}}$ casein.

The values obtained in the study are well within the range of the values observed by Nagamani, (2013). 
Molecular weight analysis of BAPs by SDSPAGE from caprine milk casein

It was revealed from SDS-PAGE electrophoretic pattern of bioactive peptides obtained from $\alpha_{\mathrm{s}}$-casein and $\beta$-casein subjected for hydrolysis was an average of 1.98 and 1.35 kilo Daltons is depicted in Table 3. The bioactive peptides obtained from caprine $\alpha_{\mathrm{s}}$-casein and $\beta$-casein found the formation of peptide aggregation was in the range of 10-40 $\mathrm{kDa}$ and 10-30 $\mathrm{kDa}$. Similarly, bioactive peptides obtained from $\beta$-casein found higher aggregation was in the range of $35-40 \mathrm{kDa}$ than $\alpha_{\mathrm{s}}$-casein during hydrolysis. Bioactive peptides derived from hydrolyzed $\beta$ casein yielded higher molecular weight peptides compared to the molecular weight of peptides derived from hydrolysed $\alpha_{\mathrm{s}}$-casein. The results obtained in the present investigation are in line with the findings of Nagmani, (2013) that molecular weight of bioactive peptides produced by bovine casein hydrolysis of $\alpha_{\mathrm{s}}$ and $\beta$-casein using trypsin enzyme were in the range of $1,900 \mathrm{Da}$ to 2,100 Da. Similarly, Adamson and Reynolds (1997), also observed that as degree of hydrolysis increased more of lower molecular weight BAPs were released, which they attributed to the production of truncated forms of peptides.

\section{RP-HPLC profile of bioactive peptides}

The RP-HPLC profile was carried out for the bioactive peptides produced after maximum hydrolysis (i.e., 15 per cent DH) from caprine casein fractions by using trypsin enzyme. The peptides released were characterized based on relative retention time which was presented in Table 4 and Graph 1. RP-HPLC analysis of BAPs isolated from caprine casein fractions hydrolysates are presented in Graph 1. It is evident from Graph 1 that, the peak retention time of bioactive peptides from $\alpha_{\mathrm{s}}$-casein was $30.034 \mathrm{~min}$. and also it is evident that, the peak retention time of bioactive peptides from $\beta$-casein hydrolysate obtained was 60.234 min. These results are in agreement with the findings of workers Miesel and Fitz Gerald. (2003) and Nagamani (2013) who showed that hydrophilicity of peptide is more important for increased binding of calcium in bioactive peptides.

Table.1 Hydrolysis of caprine milk casein fractions (DH (\%)

\begin{tabular}{|c|c|c|}
\hline Time of Hydrolysis (Min) & $\alpha_{\mathrm{S}}$-casein & $\beta$-casein \\
\hline $\mathbf{0}$ & 0.0 & $\mathbf{0 . 0}$ \\
\hline $\mathbf{1 0}$ & 1.2 & $\mathbf{1 . 5}$ \\
\hline $\mathbf{3 0}$ & 3.6 & $\mathbf{4 . 0}$ \\
\hline $\mathbf{6 0}$ & 6.5 & $\mathbf{6 . 1 3}$ \\
\hline $\mathbf{9 0}$ & 8.30 & $\mathbf{8 . 8 0}$ \\
\hline $\mathbf{1 2 0}$ & 10.17 & $\mathbf{1 0 . 5 2}$ \\
\hline $\mathbf{1 5 0}$ & 12.38 & $\mathbf{1 2 . 7 1}$ \\
\hline $\mathbf{1 8 0}$ & 15.10 & $\mathbf{1 5 . 5 5}$ \\
\hline $\mathbf{3 6 0}$ & 16.65 & $\mathbf{1 6 . 8 2}$ \\
\hline $\mathbf{1 4 4 0}$ & $\mathbf{1 9 . 1 7}$ & $\mathbf{2 0 . 2 0}$ \\
\hline
\end{tabular}

All values are average of three trials $(\mathrm{N}=3)$

Expressed as per cent Degree of Hydrolysis (DH) at an Enzyme: Substrate (E: S) ratio of 1:25

Hydrolysis at an optimum $\mathrm{pH} 8.0$ and temperature $40{ }^{\circ} \mathrm{C}$

Expressed as g of BAPs / 100g of protein

Casein fractions were hydrolyzed to a maximum of $10 \%$ Degree of Hydrolysis (DH) 
Table.2 Measurement of absorbance for quantification of Bio-active peptides (BAPs) from caprine milk casein

\begin{tabular}{|c|c|c|c|}
\hline Protein & Source of BAPs & Absorbance $($ at $595 \mathrm{~nm})$ & Quantity $(\mu \mathrm{g} / \mathrm{ml})$ \\
\hline Casein & $\alpha_{S^{-}}$casein & 0.122 & $\mathbf{2 6 . 8 0}$ \\
\cline { 2 - 4 } & $\beta$ - casein & 0.157 & $\mathbf{4 1 . 2 ~ 0 ~}$ \\
\hline & CD $(\mathbf{P} \leq \mathbf{0 . 0 5})$ & $\mathbf{0 . 0 0 6 8}$ & $\mathbf{0 . 0 3 2}$ \\
\hline
\end{tabular}

Table.3 Molecular weight Profile of BAPs from caprine milk casein

\begin{tabular}{|c|c|c|c|}
\hline Molecular weight range $(\mathrm{kDa})$ & Standard & $\alpha$ - casein & $\beta$ - casein \\
\hline$<\mathbf{1 . 0}$ & - & - & - \\
\hline $\mathbf{1 - 5}$ & - & + & + \\
\hline $\mathbf{5 - 1 0}$ & - & + & + \\
\hline $\mathbf{1 0 - 1 5}$ & - & $+\#$ &,$+ \#$ \\
\hline $\mathbf{1 5 - 2 0}$ & - &,$+ \#$ &,$+ \#$ \\
\hline $\mathbf{2 0 - 2 5}$ & + &,$+ \# \#$ &,+ \#\# \\
\hline $\mathbf{2 5 - 3 0}$ & + &,$+ \# \#$ &,+ \#\# \\
\hline $\mathbf{3 0 - 3 2}$ & + &,$+ \# \#$ &,+ \#\# \\
\hline $32-35$ & + &,$+ \# \# \#$ &,+ \#\#\# \\
\hline $35-40$ & + &,$+ \# \# \#$ &,$+ \# \# \# \#$ \\
\hline
\end{tabular}

Note: Presence of bands:

Absence of bands: $\quad$-;

Peptides Aggregation: \#.

All values are expressed as kilo Dalton $(\mathrm{kDa})$

All values are average of three trial

Table.4 RP-HPLC profile of bioactive peptides

\begin{tabular}{|c|c|}
\hline Source of BAPs & Retention time $(\mathrm{min})$ \\
\hline$\alpha_{S^{-}}$casein & $\mathbf{3 0 . 0 3 4}$ \\
\hline$\beta$ - casein & $\mathbf{6 0 . 2 3 4}$ \\
\hline א- casein & $\mathbf{5 . 2 8 0}$ \\
\hline
\end{tabular}

- All the values are average of three trials

- Control: Unhydrolysed caprine milk casein fraction

Graph.1 RP-HPLC profile of BAPs

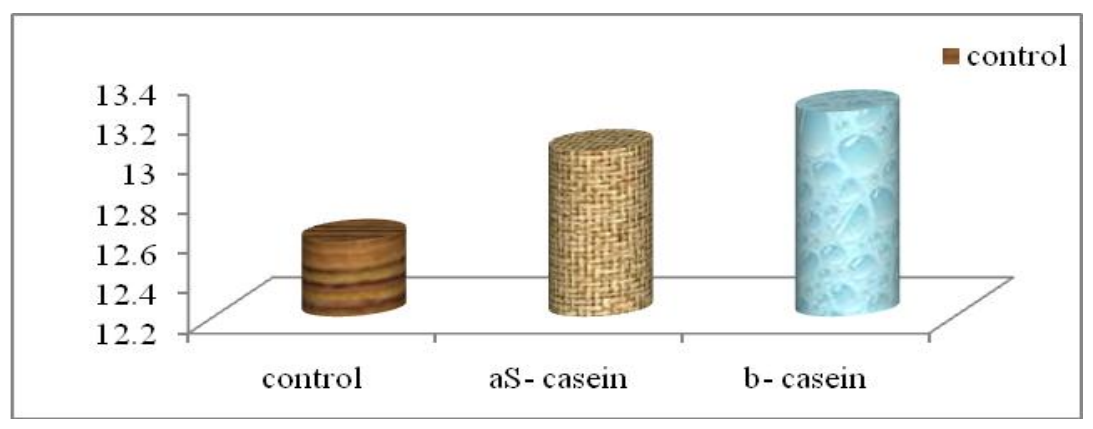


It is concluded that caprine milk proteins contains casein and whey proteins. The average casein and whey protein content of cow milk protein was 2.64 and 0.66 per cent and caprine milk protein was 2.58 and 0.63 per cent respectively. The casein fractions $\left(\alpha_{\mathrm{s}}\right.$ and $\beta$-casein) were subjected for enzymatic modification, the optimum degree of hydrolysis (i.e. ${ }^{\approx} 15$ per cent $\mathrm{DH}$ ) was achieved at an Enzyme: Substrate (E:S) ratio of 1:25 at a given concentration of the enzyme, the higher degree of hydrolysis was observed and the yield of $\beta$-casein hydrolysate (75-92\%) was higher compared to the yield of BAPs of $\alpha_{s^{-}}$casein hydrolysate. The bioactive peptides obtained from caprine $\alpha_{\mathrm{s}}$-casein and $\beta$-casein found the formation of peptide aggregation was in the range of $10-$ $40 \mathrm{kDa}$ and 10- $30 \mathrm{kDa}$. Similarly, bioactive peptides obtained from $\beta$-casein found higher aggregation was in the range of $30-54.236$ $\mathrm{kDa}$ than $\alpha_{\mathrm{s}}$-casein during hydrolysis. The RP-HPLC profile of BAPs of hydrolyzed $\beta$ casein showed higher retention time (60.234 min) for hydrophilic peptides than BAPs obtained from $\alpha_{\mathrm{s}}$-casein hydrolysates (30.034 min). The peak retention time was higher in case of hydrophilic peptides as they eluted slower when compared to hydrophobic peptides. The retention time is directly related to polar nature of peptides.

\section{References}

Adamson, N.J. and Reynolds, E. C. 1997. Relationship between degree of casein hydrolysis and phosphopeptide release. Journal of Dairy Research., 64(6): 505514

AOAC., 1984. Official methods of analysis $13^{\text {th }}$ Ed., Association of official Agricultural Chemist, Washington, D.C.

AOAC., 1980. Official methods of analysis $13^{\text {th }}$ Ed., Association of official Agricultural Chemist, Washington, D.C. Bradford, M. M., 1976. A rapid and sensitive method for the quantitation of microgram quantities of protein utilizing the principle of protein-dye binding. Analytical Biochemistry., 72 (1-2): 248-254.

Fitz Gerald, R. J., 1998. Potential uses of caseinophosphopeptides. International Dairy Journal., 8 (5-6): 451-457

Hipp, N.J., Groves, M.L., Custer, J.H. and Mcmeekin, T.L., 1952. Separation of $\alpha \mathrm{s}^{-}, \beta$-and $\gamma$-Casein. Journal of Dairy Science., 35(3):272-281.

Korhonen, H., and Pihlanto, A., 2003. Food derived bioactive peptides opportunities for designing future foods. Current Pharmaceutical Design., 9: 1297 - 1308.

Mcdonagh, D. and Fitzgerald, R.J., 1998. Production of caseinophosphopeptides (CPPs) from sodium caseinate using a range of commercial

Meisel, H. and Fitz Gerald, R. J., 2003. Biofunctional peptides from milk proteins: mineral binding and cytomodulatory effects. Curr Pharm Des., 9: 1289-1295.

Nagamani. A., 2013. Characterization and immunomodulatory activity of buffalo milk bio-activity peptides in weaning foods. Ph.D. Thesis submitted to Karnataka Veterinary, Animal and Fisheries Sciences University, Bidar, India.

Naik, L. Mann, B.Bajaj, R. R. B. Sangwan, R.B. and Sharma, R., 2013. Process Optimization for the production of biofunctional whey protein hydrolysates: Adopting response surface methodology. International Journal of Peptide Research Therapeutics., 19:231-237.

Sharma, G. Rout, P.K and Singh, G., 2017. Characterization of goat milk protein and comparison of milk proteins using polyacrylamide gel electrophoresis. International Journal of Scientific 
Engineering and Applied Science., 3(4): 2395- 3470.

Shashikumar, C.S., 2012. Development of functional weaning food enriched with calcium and iron binding bioactive peptides. Ph.D thesis submitted to Karnataka Veterinary, Animal and Fisheries Sciences University, Bidar,
India.

Snedecor, G.M. and Cochran, W.G., 1983. Statistical Methods. Oxford and IBH Publishing Company., 60-65.

Tziboula-Clarke, A., 2003. Encyclopedia of Dairy Science. Vol. 2, Academics Press, California, USA.

\section{How to cite this article:}

Devaraja Naik, H., M. Venkatesh and Arun Kumar, H. 2018. Isolation and Characterisation of Bioactive Peptides Components from Caprine Milk Casein Fractions. Int.J.Curr.Microbiol.App.Sci. 7(11): 2020-2026. doi: https://doi.org/10.20546/ijcmas.2018.711.229 